\title{
Determination of Vitamin C (Ascorbic Acid) Using High Performance Liquid Chromatography Coupled with Electrochemical Detection
}

\author{
Zbynek Gazdik ${ }^{1,2}$, Ondrej Zitka ${ }^{3}$, Jitka Petrlova ${ }^{3}$, Vojtech Adam ${ }^{3,4}$, Josef Zehnalek ${ }^{3}$, \\ Ales Horna ${ }^{5}$, Vojtech Reznicek ${ }^{1}$, Miroslava Beklova ${ }^{6}$ and Rene Kizek ${ }^{3, *}$
}

1 Department of Breeding and Propagation of Horticultural Plants, Faculty of Horticulture, Valticka 337, CZ-691 44 Lednice, Faculty of Agronomy, Zemedelska 1, CZ-613 00 Brno, Mendel University of Agriculture and Forestry, Czech Republic

2 Department of Agrochemistry, Soil Science, Microbiology and Plant Nutrition, Faculty of Agronomy, Zemedelska 1, CZ-613 00 Brno, Mendel University of Agriculture and Forestry, Czech Republic

3 Department of Chemistry and Biochemistry, Faculty of Agronomy, Zemedelska 1, CZ-613 00 Brno, Mendel University of Agriculture and Forestry, Czech Republic

4 Department of Animal Nutrition and Forage Production, Faculty of Agronomy, Zemedelska 1, CZ61300 Brno, Mendel University of Agriculture and Forestry, Czech Republic

5 Tomas Bata University, T.G. Masaryka 275, CZ-762 72 Zlin, Czech Republic

6 Department of Veterinary Ecology and Environmental Protection, Faculty of Veterinary Hygiene and Ecology, University of Veterinary and Pharmaceutical Sciences, Palackeho 1-3, CZ-612 42 Brno, Czech Republic

* Author to whom correspondence should be addressed; E-mail:kizek@sci.muni.cz

Received: 4 August 2008; in revised form: 4 November 2008 / Accepted: 6 November 2008 / Published: 7 November 2008

Abstract: Vitamin C (ascorbic acid, ascorbate, AA) is a water soluble organic compound that participates in many biological processes. The main aim of this paper was to utilize two electrochemical detectors (amperometric - Coulouchem III and coulometric CoulArray) coupled with flow injection analysis for the detection of ascorbic acid. Primarily, we optimized the experimental conditions. The optimized conditions were as follows: detector potential $100 \mathrm{mV}$, temperature $25{ }^{\circ} \mathrm{C}$, mobile phase $0.09 \%$ TFA:ACN, 
3:97 $(v / v)$ and flow rate $0.13 \mathrm{~mL} \cdot \mathrm{min}^{-1}$. The tangents of the calibration curves were 0.3788 for the coulometric method and 0.0136 for the amperometric one. The tangent of the calibration curve measured by the coulometric detector was almost 30 times higher than the tangent measured by the amperometric detector. Consequently, we coupled a CoulArray electrochemical detector with high performance liquid chromatography and estimated the detection limit for AA as $90 \mathrm{nM}$ (450 fmol per $5 \mu \mathrm{L}$ injection). The method was used for the determination of vitamin $C$ in a pharmaceutical preparations $(98 \pm 2 \mathrm{mg}$ per tablet), in oranges (Citrus aurantium) (varied from 30 to $56 \mathrm{mg} / 100 \mathrm{~g}$ fresh weight), in apples (Malus sp.) (varied from 11 to $19 \mathrm{mg} / 100 \mathrm{~g}$ fresh weight), and in human blood serum (varied from 38 to $78 \mu \mathrm{M}$ ). The recoveries were also determined.

Keywords: Ascorbic Acid; Flow Injection Analysis; High Performance Liquid Chromatography; Electrochemical Detection; Fruits; Pharmaceutical Preparation; Human Blood Serum

\section{Introduction}

\subsection{Biological function of vitamin $C$}

Vitamin C (ascorbic acid, ascorbate, AA) is a water soluble organic compound involved in many biological processes (Figure 1). AA plays crucial roles in electron transport, hydroxylation reactions and oxidative catabolism of aromatic compounds in animal metabolism [1]. Although all the functions of AA are not fully explained, it is likely that it is also involved in maintaining the reduced state of metal cofactors, for example at monooxygenase $\left(\mathrm{Cu}^{+}\right)$and dioxygenase $\left(\mathrm{Fe}^{2+}\right)$ [2]. In cells the other role of AA is to reduce hydrogen peroxide $\left(\mathrm{H}_{2} \mathrm{O}_{2}\right)$, which preserves cells against reactive oxygen species [3-5]. An oxidation cycle of ascorbic acid to dehydroascorbic acid is shown in Figure 1. The details about ascorbic acid antioxidant system cooperated with glutathione was described by Meister [6]. Besides this, primates and several other mammals are not able to synthesise ascorbic acid [5]. The animal species, which are able to produce this molecule, biosynthesise AA from glucose catalyzed Lgulonolactonoxidase $[1,2]$. In spite of the ability to synthesize this molecule both groups of animal species suffer from deficiency of AA $[1,2]$.

\subsection{Daily needs of vitamin C}

The only way humans uptake ascorbic acid is via food [7], but the daily needs of vitamin C for a human are not clear yet. Linus Pauling postulated that people's needs for vitamins and other nutrients vary markedly and that to maintain good health, many people need amounts of nutrients much greater than the recommended doses. According to his suggestions, daily uptake of vitamin $\mathrm{C}$ has to be within units of grams of AA to reduce the incidence of colds and other diseases. These "huge" amounts of AA have not been ever proved as the reason for large reducing of the incidence of illnesses. Nowadays 
the estimated average requirement and recommended dietary allowance of ascorbic acid are $100 \mathrm{mg}$ per day and $120 \mathrm{mg}$ per day, respectively $[8,9]$.

\subsection{Content of vitamin $C$ in foods}

AA can be mostly found in fruits and vegetables. The main sources of AA are citrus fruits, hips, strawberries, peppers, tomatoes, cabbage, spinach and others [3]. If one wants to uptake AA from animal sources, liver and kidney are the tissues with highest contents of this molecule, but in comparison with plant sources the amount of AA is very low [10]. The content of AA in food can be affected by many factors such as clime, method of harvest, storing and processing. Thus, there is a need of analytical procedures able to not only monitor AA content in agricultural and food products, but also in body liquids and tissues [11]. Authors also paid their attention at detection of AA in blood serum [12-15].

Figure 1. Scheme of a biological function of ascorbic acid (GSH - reduced glutathione, GSSG - oxidized glutathione).

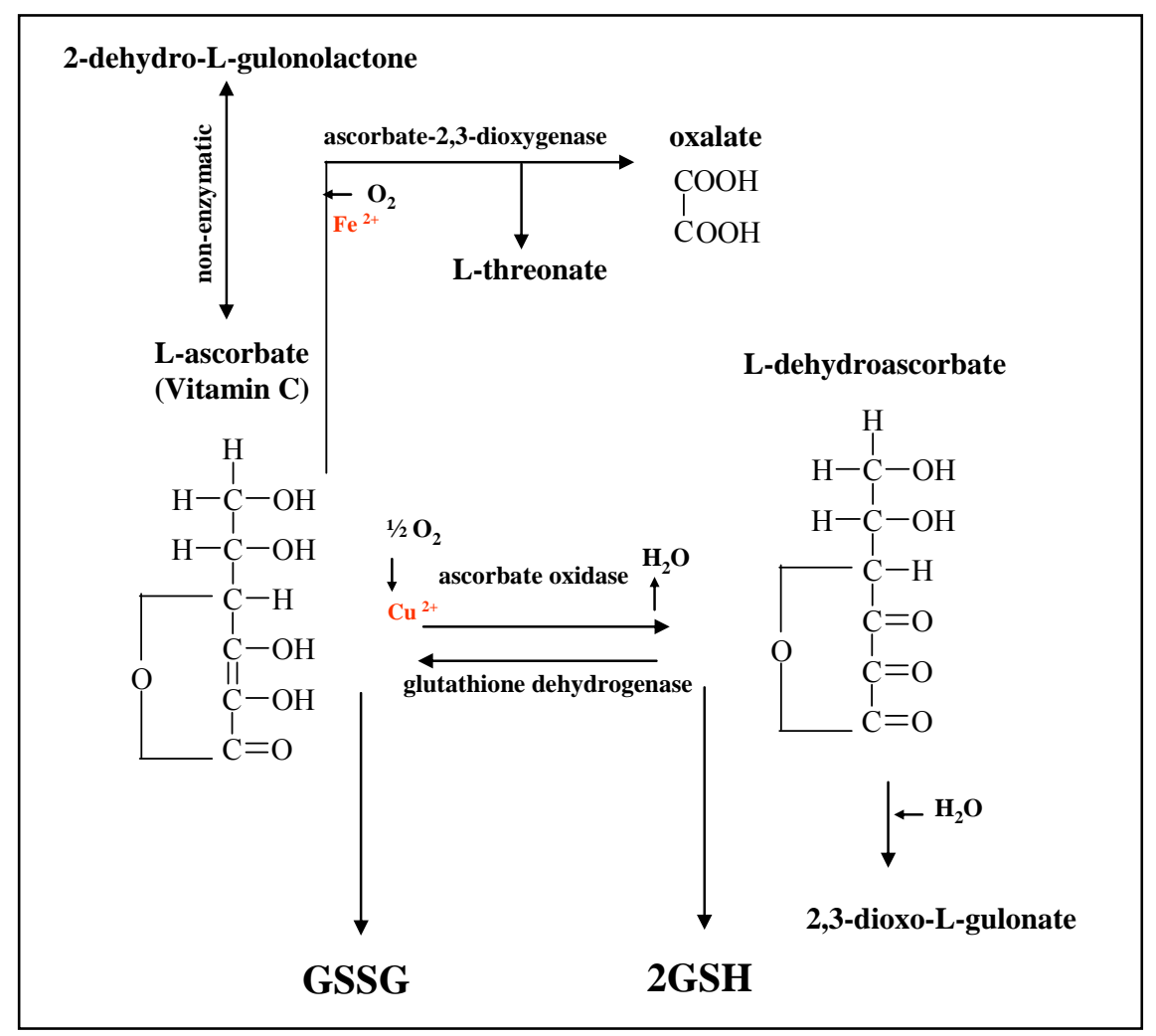

\subsection{Methods for ascorbic acid determination}

Many analytical techniques including sensors and biosensors [16-18] have been suggested for a detection of ascorbic acid in very varied types of samples. Hyphenated instruments consisting of flow injection analysis [19-22], high performance liquid chromatography [23-25] or capillary electrophoresis [26-29] instruments and a detector are mostly utilized for the determination of AA. However, some of these methods are time-consuming, some are costly, some need special training 
operators, or they suffer from the insufficient sensitivity or selectivity. Limits of detection ranged from $\mu \mathrm{M}$ [30-32] to $\mathrm{nM}$ [33-36] and lower [12].

Electrochemical detection is an attractive alternative method for detection of electroactive species, because of its inherent advantages of simplicity, ease of miniaturization, high sensitivity and relatively low cost. Electrochemical detection typically worked in amperometric or coulometric mode can be coupled with liquid chromatography to provide high sensitivity to electroactive species. The main aim of this paper is to utilize two electrochemical detectors (amperometric - Coulouchem III and coulometric - CoulArray) coupled with flow injection analysis for detection of ascorbic acid. The more sensitive technique is further applied on analysis of real samples (pharmaceutical preparation, oranges and apples fruits, and human blood serum).

\section{Material and Methods}

\subsection{Chemicals, material and pH measurements}

HPLC-grade acetonitrile ( $>99.9 \%$; v/v) from Merck (Darmstadt, Germany) was used. Other chemicals used were purchased from Sigma-Aldrich (St. Louis, USA) in ACS purity unless noted otherwise. Stock standard solutions of the AA $(100 \mathrm{mM})$ were prepared with ACS water (SigmaAldrich, USA) and stored in the dark at $-20{ }^{\circ} \mathrm{C}$. Working standard solutions were prepared daily by dilution of the stock solutions. The stability of AA in samples is strongly influenced by oxygen, which oxidises AA to dehydroascorbic acid. To avoid direct an oxidation reducing agents or acidification by acids can be used [37]. Here, we used dithiothreitol (DTT). All solutions were filtered through $0.45 \mu \mathrm{m}$ Nylon filter discs (Millipore, Billerica, Mass., USA) prior to HPLC analysis. The $\mathrm{pH}$ value was measured using WTW inoLab (Weilheim, Germany), controlled by software MultiLab Pilot. The pHelectrode was regularly calibrated with WTW buffers (Weilheim, Germany).

\subsection{Flow injection analysis/High performance liquid chromatography with CoulArray or Coulochem electrochemical detector}

CoulArray. The FIA/HPLC-ED system consisted of two solvent delivery pumps operating in the range 0.001-9.999 $\mathrm{mL} \cdot \mathrm{min}^{-1}$ (Model $582 \mathrm{ESA}$ Inc., Chelmsford, MA), a reaction coil $(1 \mathrm{~m})$ and/or Metachem Polaris C18A reversed-phase column $(150.0 \times 2.1 \mathrm{~mm}, 3 \mu \mathrm{m}$ particle size; Varian Inc., CA, USA) and a CoulArray electrochemical detector (Model 5600A, ESA, USA). The electrochemical detector includes two flow cells (Model 6210, ESA, USA). Each cell consists of four analytical cells containing working carbon porous electrode, two auxiliary and two reference electrodes. Working electrodes were polished electrochemically applying of positive/negative potential cycles $(1 /-1 \mathrm{~V})$ at increased flow of the mobile phase $\left(1 \mathrm{~mL} \cdot \mathrm{min}^{-1}\right)$. Both the detector and the reaction coil/column were thermostated. The sample $(5 \mu \mathrm{L})$ was injected manually.

Coulochem III. The FIA-ED system consisted of a solvent delivery pump operating in range of 0.001-9.999 $\mathrm{mL} \cdot \mathrm{min}^{-1}$ (Model 583 ESA Inc., Chelmsford, MA, USA), a guard cell (Model 5020 ESA, USA), a reaction coil $(1 \mathrm{~m})$ and an electrochemical detector. The electrochemical detector (ED) includes one low volume flow-through analytical cells (Model 5040, ESA, USA), which is consisted 
of glassy carbon working electrode, palladium electrode as reference electrode and auxiliary carbon electrode, and Coulochem III as a control module. A glassy carbon electrode was polished mechanically by $0.1 \mu \mathrm{m}$ of alumina (ESA Inc., USA) and sonicated at the laboratory temperature for 5 min using a Sonorex Digital 10 P Sonicator (Bandelin, Berlin, Germany) at $40 \mathrm{~W}$ as it was described by [38]. The sample $(5 \mu \mathrm{L})$ was injected manually. The obtained data were treated by CSW 32 software. The experiments were carried out at room temperature.

\subsection{Preparation of real samples}

The pharmaceutical preparation (a tablet) - Celaskon (Leciva, Prague, Czech Republic) was ground in a mortar $(n=5)$. Then, ground powder (about $1 \mathrm{mg})$ was dissolved in ACS water $(1 \mathrm{~mL})$. Oranges and apples (Citrus aurantium and Malus sp.) were bought at TESCO stores $(n=5)$. The pericarps of the fruits were removed, and then the fruits (app. $0.25 \mathrm{~g}$ ) were homogenized using a mortar. The extracts obtained were filtered through filter paper (Niederschlag, Germany), transferred into a volumetric flask and diluted with ACS water. Measurements of the samples were carried out immediately after preparation steps. Human blood serum samples were obtained from the Department of Clinical Biochemistry, Trauma Hospital Brno (Czech Republic), $(n=10)$. Human sera were frozen at $-20{ }^{\circ} \mathrm{C}$ immediately after collection. The samples were $100 \times$ diluted with ACS water and filtered through $0.45 \mu \mathrm{m}$ Teflon membrane filter prior to measurement.

\subsection{Accuracy, precision and recovery}

Accuracy, precision and recovery of AA were evaluated with homogenates (human blood serum, a fruit and Celaskon tablets) spiked with the standard. Before extraction, AA standards $(100 \mu \mathrm{L})$ and water $(100 \mu \mathrm{L})$ were added to the homogenates of real samples. The homogenates were assayed blindly and AA concentrations were derived from the calibration curves. Accuracy was evaluated by comparing estimated concentrations with known concentrations of AA. Calculation of accuracy (\% Bias), precision (\% C.V.) and recovery was carried out as indicated by [39-41].

\subsection{Descriptive statistics}

Data were processed using MICROSOFT EXCEL® (USA). Results are expressed as mean \pm S.D. unless noted otherwise. The detection limits ( 3 signal/noise, $\mathrm{S} / \mathrm{N}$ ) were calculated according to Long and Winefordner [42], whereas $\mathrm{N}$ was expressed as standard deviation of noise determined in the signal domain unless stated otherwise.

\section{Results and Discussion}

Stationary and flow electrochemical techniques are very attractive instruments for determining various biologically important compounds such as proteins [43-60], organic compounds of plant origin [61-66], drugs [67-70], etc. Here, we aimed at utilizing two different electrochemical detectors - 
amperometric (Coulouchem III) or coulometric (CoulArray) coupled with high performance liquid chromatography for detection of ascorbic acid.

\subsection{Flow injection analysis coupled with CoulArray electrochemical detector to detect ascorbic acid}

An electrochemical behaviour of AA at the surface of working electrodes was investigated. FIA enables us to optimise experimental conditions for analytical determination of AA easily and rapidly. Primarily, the influence of potential applied to single working electrodes on oxidation signal of AA was studied. The potential varied from 100 to $400 \mathrm{mV}$ and signal of various concentration of AA $(12.5,25,50,100,200,300,400,500$ and $1000 \mu \mathrm{M})$ was measured.

Figure 2. FIA coupled with CoulArray electrochemical detector. FIA-ED full scan of ascorbic acid $(12.5,25,50,100,200,300,400,500$ and $1000 \mu \mathrm{M})$. Detector electrodes potentials at full scan: 100, 150, 200, 250, 300, 350, 380 and $400 \mathrm{mV}$ (A). Dependence of ascorbic acid peak height on detector temperature $(\mathbf{B})$, on content of acetonitrile in mobile phase consisted from acetonitrile and trifluoroacetic acid (C) and on TFA concentration (D). FIA-ED parameters: flow rate of mobile phase $-0.1 \mathrm{~mL} \cdot \mathrm{min}^{-1}$; ascorbic acid concentrations $-100 \mu \mathrm{M} ; 5 \mu \mathrm{L}$ samples was injected.

FIA coupled with CoulArray electrochemical detector

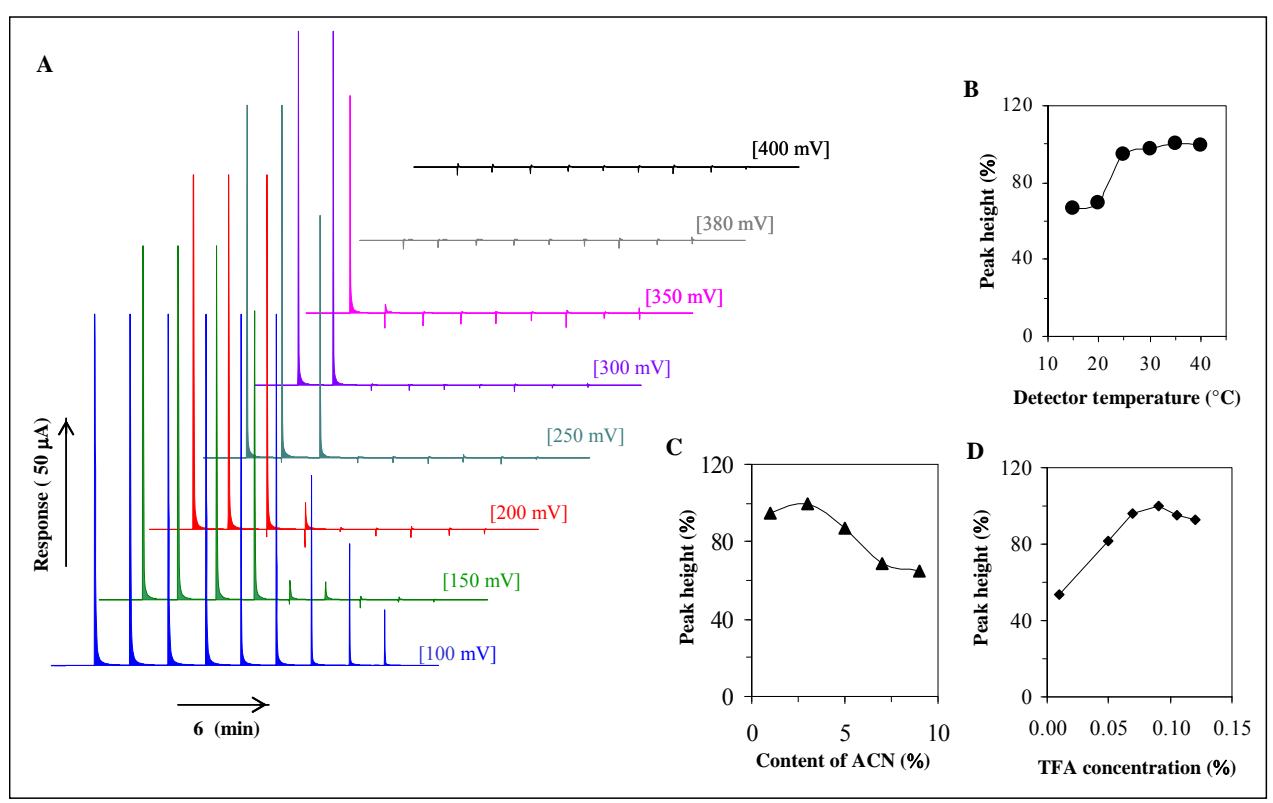

Each concentration belongs to the signal shown in FIA-ED record in Figure 2A. Apparently maximal current responses were measured at the surface of the first working electrode. This phenomenon was observed at all concentrations of AA measured by FIA-ED. Moreover it can be concluded that lower concentration of AA was measured, the signal disappeared earlier (Figure 2A). This phenomenon associates with i) type of detector used because CoulArray detector operates in coulometry mode and coulometric detector promotes near $100 \%$ electrochemical conversion of analytes below the designated potential of the detector, and with ii) easy electrochemical oxidation of $\mathrm{AA}$ at the surface of the working electrodes already under low potentials (about 100-200 mV). For 
choosing of the optimal potential for detection of AA, we applied the potential scale from 100 to 400 $\mathrm{mV}$ per $50 \mathrm{mV}$ at all eight electrodes and measured the signal at the first electrode only. Based on these results, the most suitable potential for detection of AA was $100 \mathrm{mV}$.

Further, the affecting height of the signal of AA by temperature was studied. The temperature within the range from 15 to $40{ }^{\circ} \mathrm{C}$ was tested. The dependence obtained is shown in Figure $2 \mathrm{~B}$. The peak height increased for more than $30 \%$ at $25{ }^{\circ} \mathrm{C}$ compared to signals obtained at lower temperatures $\left(15\right.$ and $\left.20^{\circ} \mathrm{C}\right)$. At temperatures higher than $25^{\circ} \mathrm{C}$ very low changes in the height was observed (Figure 2B). Therefore temperature of $25^{\circ} \mathrm{C}$ was used in the following experiments.

It is commonly known that electrochemical analysis needs the presence of an electrolyte, although the presence of a non-aqueous solvent in a mobile phase is needed for successful and rapid simultaneous determination of compounds of interest. These non-aqueous solvent negatively influence electrochemical analysis [41,71]. Therefore, affecting of AA signal by the ratio of acetonitrile:trifluoroacetic acid (ACN:TFA, v/v) was investigated (Figure 2C). We did not determine any changes in repeatability with increasing content of ACN in mobile phase. The highest signal was measured at $3 \%(v / v)$ content of ACN in the mobile phase.

Figure 3. Effect of AA concentration. Dependence of peak height on different AA concentrations $(15,30,55,85,110$ and $140 \mu \mathrm{M})(\mathbf{A})$. Human blood serum. Influence of biological matrix on AA signal. Concentration of AA - 57, 114, 227 and $341 \mu \mathrm{M}$ (B). FIAED parameters were as follows: mobile phase - acetonitrile and $0.09 \%$ trifluoroacetic acid in ratio $3: 97$; detector temperature $-25^{\circ} \mathrm{C}$; flow rate of mobile phase $-0.13 \mathrm{~mL} \cdot \mathrm{min}^{-1} ; 5$ $\mu \mathrm{L}$ samples was injected.

FIA coupled with CoulArray electrochemical detector

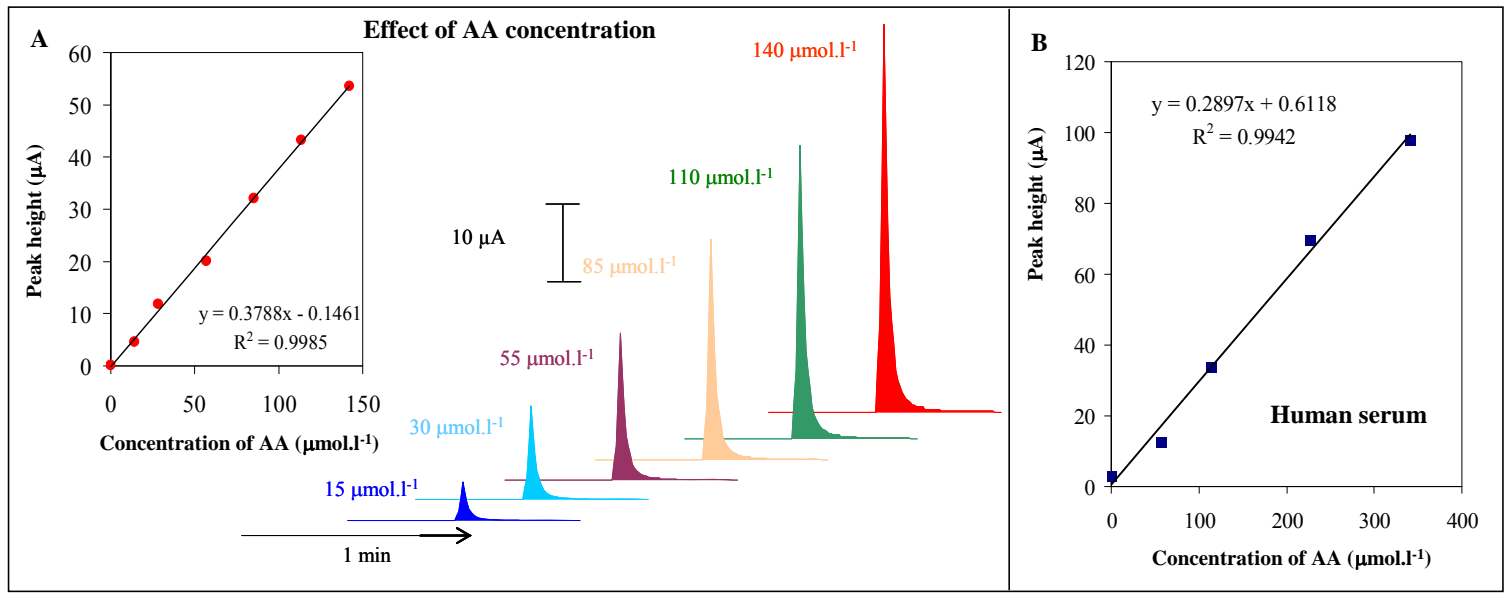

It is a common knowledge that trifluoroacetic acid (TFA) is ion pairing agent in liquid chromatography that can react with the vitamin and may assign them charge. Thus, we selected a mixture of acetonitrile with aqueous solution of trifluoroacetic acid at ratio 3:97 (v/v) and tested the influence of various concentrations of TFA. We found out that the response increased to $0.005 \%$ concentration of TFA, then slightly decreased. The highest signal of AA was measured at $0.09 \%$ TFA:ACN, 3:97 ( $v / v)$ (Figure 2D). Moreover, flow rate of the mobile phase is other important parameter influencing peak height. We tested the flow of mobile phase from 0.05 to $0.2 \mathrm{~mL} \cdot \mathrm{min}^{-1}$. The highest current responses were obtained at flow $0.13 \mathrm{~mL} \cdot \mathrm{min}^{-1}$. 
The optimal experimental conditions are: detector potential $100 \mathrm{mV}$, temperature $25{ }^{\circ} \mathrm{C}$, mobile phase $0.09 \%$ TFA:ACN, $3: 97(v / v)$ and its flow rate $0.13 \mathrm{~mL} \cdot \mathrm{min}^{-1}$. Under these conditions we measured the dependence of AA peak height on its concentration. The peaks obtained were well developed and symmetrical (insets in Figure 3A). The calibration curve is shown in Figure $3 \mathrm{~A}(\mathrm{y}=$ $\left.0.3788 \mathrm{x}-0.1461 ; \mathrm{R}^{2}=0.9985\right)$. The detection limit $(3 \mathrm{~S} / \mathrm{N})$ for AA was evaluated as 100 fmol per 5 $\mu \mathrm{L}$ injection. Further the method was utilized for determination of AA spiked into human blood serum samples. AA was spiked into blood serum $(100 \times$ diluted $)$ and electrochemical responses were observed. The obtained calibration curve $\left(y=0.2897 x+0.6118 ; R^{2}=0.9942\right)$ is shown in Figure 3B. The detection limit $(3 \mathrm{~S} / \mathrm{N})$ was evaluated as 20 pmol for a $5 \mu \mathrm{L}$ injection.

\subsection{Flow injection analysis coupled with Coulochem III electrochemical detector to detect AA}

Coulochem III is an amperometric detectors, which are somewhat inefficient because only a fraction of analyte (typically 5-10\%), which passes over the working electrode, actually diffuses onto the electrode surface and experiences electrochemical conversion [72]. One may suggest that coulometric detector CoulArray should be 10-20 times more sensitive than amperometric detection simply because of improved mass transfer. Unfortunately the increased conversion efficiency of the analyte is accompanied by a similar increase for the electrolyte (background) reactions, and nearly no lowering of detection limits is realized [72]. Moreover, amperometry can provide better LOD in terms of concentrations with miniaturized cells. Therefore we adopted above optimized experimental conditions to detect AA by FIA coupled Coulochem III electrochemical detector and aimed on comparison of amperomeric and coulometric detectors. Unlike CoulArray amperometric detector Coulochem contains a device called "Guard cell", which can oxidize electroactive impurities in mobile phase and, thus, lower the noise. We tested five potentials (-100, -50, 0, 50 and $100 \mathrm{mV})$ applied on Guard cell and measured the signal of AA. The dependence obtained is shown in Figure 4A. Based on the results obtained the optimal Guard cell potential was $0 \mathrm{mV}$. The potentials lower or higher than the optimal value slightly decreased the signal of AA. This phenomenon can be associated to easy electrochemical conversion of the target molecule already at Guard cell. To compare the detectors we again measured the dependence of AA concentration on peak height (Figure 4B). The equation of the calibration curve obtained was $y=0.0136 x+0.0189$, with $\mathrm{R}^{2}=0.9990$.

The concentration range of AA analysed using both coulometric and amperometric detectors was almost the same due to possibility of comparing of the sensitivity of the instruments. The tangents of the calibration curves were 0.3788 for coulometric and 0.0136 for amperometric. Based on these results the tangent of calibration curve for AA measured using coulometric detector was almost 30 times higher than the tangent measured by amperometric detector. Coulometric detector is much more sensitive to presence of AA, thus, we utilized this detector in following experiments. 
Figure 4. FIA coupled with Coulochem III electrochemical detector. Dependence of peak height on Guard cell potentials $(-100,-50,0,50$ and $100 \mathrm{mV})(\mathbf{A})$ and different AA concentrations $\left(15,30,55,85,110\right.$ and $\left.140 \mu \mathrm{mol} \cdot \mathrm{L}^{-1}\right)(\mathbf{B})$. FIA-ED parameters were the same as shown in Figure 3.

FIA coupled with Coulochem III electrochemical detector

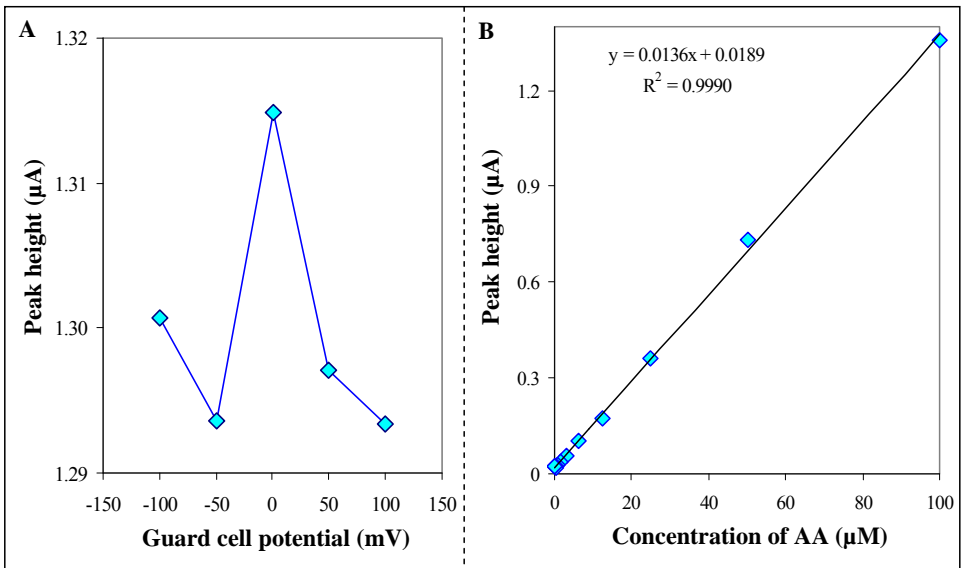

Figure 5. HPLC-ED detection of ascorbic acid. HPLC-ED chromatogram of ascorbic acid $(10 \mu \mathrm{M})(\mathbf{A})$. Dependence of peak area on different AA concentrations in the range from $0.5-20 \mathrm{mM}(\mathbf{B})$ and $10-90 \mu \mathrm{M}(\mathbf{C})$. HPLC-ED parameters were as follows: chromatographic column - MetaChem Polaris C18A $(150 \times 2.0 \mathrm{~mm}, 3 \mu \mathrm{m}$ particle size $)$ mobile phase - acetonitrile and $0.09 \%$ trifluoroacetic acid in ratio 3:97; detector temperature $-25^{\circ} \mathrm{C}$; flow rate of mobile phase $-0.13 \mathrm{~mL} \cdot \mathrm{min}^{-1}$; all detectors potential $-150 \mathrm{mV} ; 5 \mu \mathrm{L}$ samples was injected.

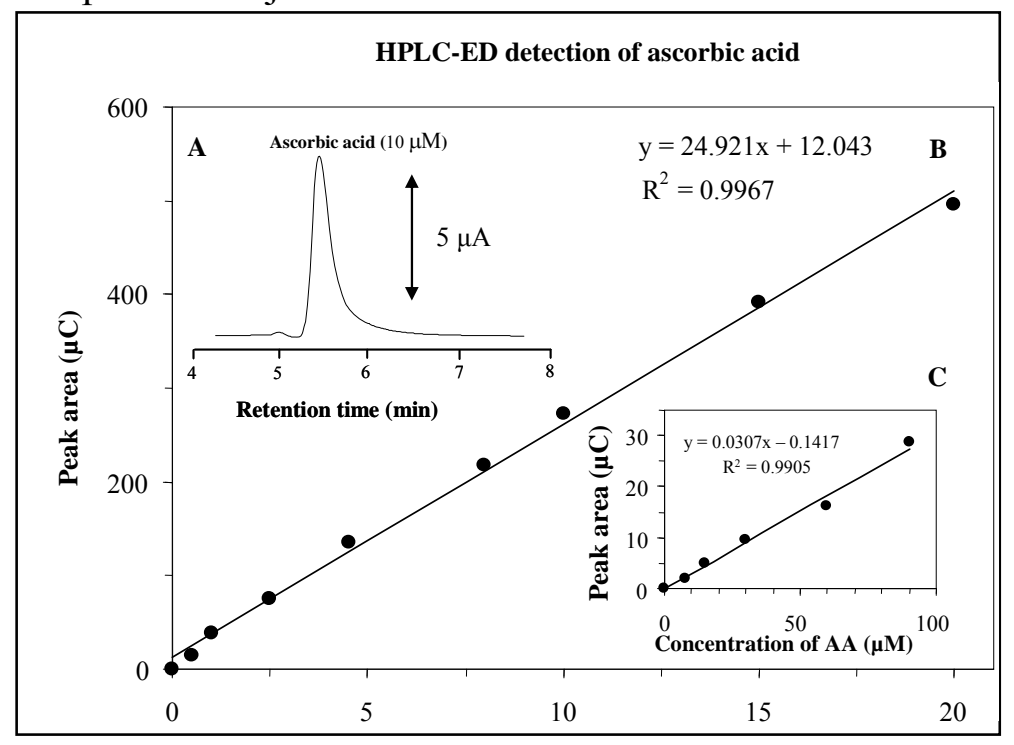

3.3 High performance liquid chromatography coupled with CoulArray electrochemical detector to $\operatorname{detect} A A$

Under the optimized conditions mentioned above ascorbic acid was measured using high performance liquid chromatography coupled with CoulArray electrochemical detector (HPLC-ED). The retention time of AA was 5.4 min. (Figure 5A). Dependence of peak area on AA concentration 
was strictly linear and relative standard deviation (R.S.D.) was about $6 \%(n=5)$. Equation of calibration curve measured within the range from 0.5 to $20 \mathrm{mM}$ of AA was $\mathrm{y}=24.921 \mathrm{x}+12.043$ with $\mathrm{R}^{2}=0.9967$ (Figure 5B). In addition we attempted to analyse lower concentration range from 10 to 90 $\mu \mathrm{M}$. The calibration curve obtained was $\mathrm{y}=0.0307 \mathrm{x}-0.1417 ; \mathrm{R}^{2}=0.9905$ (Figure 5C). Using the optimized HPLC-ED it was possible to detect nanomolar concentrations of AA (LOD: $90 \mathrm{nM} ; 450$ fmol per $5 \mu \mathrm{L}$ injection).

Figure 6. Typical HPLC-ED chromatograms of pharmaceutical preparation, extracts from apples and oranges, and human blood serum. For HPLC-ED parameters see caption of Figure 5.

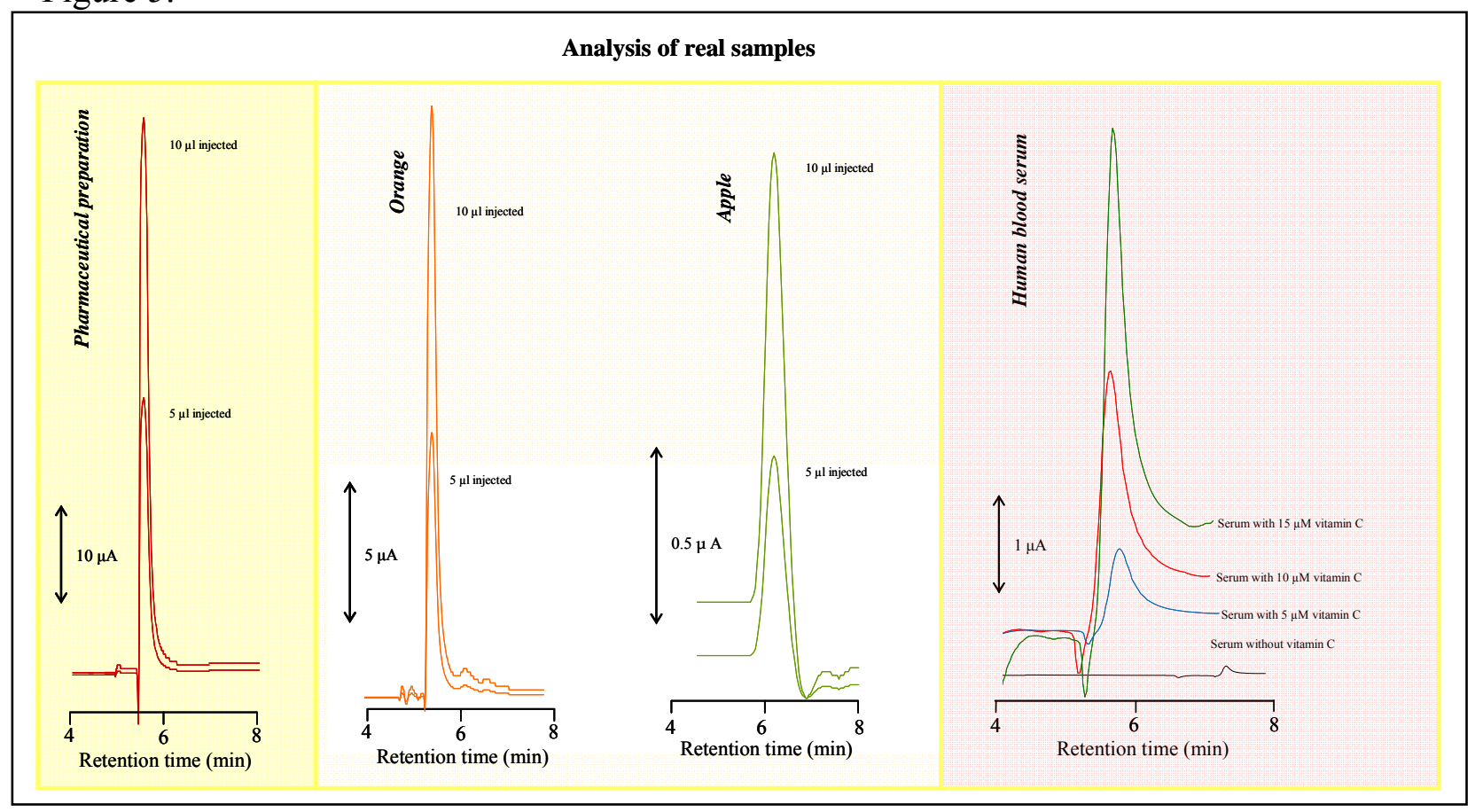

\subsection{Analysis of real samples}

The concentration of ascorbic acid was determined in pharmaceutical preparation, two species of fruits and human blood serum under the optimized experimental conditions using HPLC coupled with CoulArray electrochemical detector. Typical HPLC-ED chromatograms of the fore-mentioned samples are shown in Figure 6. We determined the concentration of ascorbic acid as $98 \pm 2 \mathrm{mg}$ per one tablet in a pharmaceutical preparation called Celaskon. The manufacturer of this preparation declares the amount of AA as $100 \mathrm{mg}$ per tablet. The recovery of the amount of AA added into the sample was 105 $\%$ for lower addition of AA $\left(5 \mu \mathrm{g} \cdot \mathrm{mL}^{-1}\right)$ and $95 \%$ for higher addition of AA $\left(15 \mu \mathrm{g} \cdot \mathrm{mL}^{-1}\right)$; for more details see in Table 1. Moreover we used HPLC-ED to determine AA concentration in fruits species. We found that AA amount in oranges (Citrus aurantium) varied in the range from 30 to $56 \mathrm{mg} / 100 \mathrm{~g}$ of fresh weight and in apples (Malus sp.) from 11 to $19 \mathrm{mg} / 100 \mathrm{~g}$ of fresh weight. The recovery of AA measured in the homogenate prepared from fruits Citrus aurantium was $103 \%$ for lower addition (5 $\left.\mu \mathrm{g} \cdot \mathrm{mL}^{-1}\right)$ and $104 \%$ for higher addition $\left(15 \mu \mathrm{g} \cdot \mathrm{mL}^{-1}\right)$; Table 1 . To evaluate HPLC-ED technique for analysis of human body liquids we spiked human blood serum and found out that recovery of AA 
varied from 102 to $98 \%$ according to lower $\left(5 \mu \mathrm{g} \cdot \mathrm{mL}^{-1}\right)$ or higher $\left(15 \mu \mathrm{g} \cdot \mathrm{mL}^{-1}\right)$ content of AA. The tested blood sera contained AA within the range from 38 to $78 \mu \mathrm{M}$.

Table 1. Recovery of AA for orange fruit (Citrus aurantium), Celaskon tablet and human serum sample analysis $(n=3)$.

\begin{tabular}{|c|c|c|c|c|}
\hline Sample & $\begin{array}{l}\text { Homogenate } \\
\left(\mu g \mathrm{~mL}^{-1}\right)^{\mathrm{a}, \mathrm{b}, \mathrm{c}}\end{array}$ & $\begin{array}{l}\text { Spiking AA } \\
\left.(\mu \mathrm{g} \mathrm{mL})^{-1}\right)^{\mathrm{a}, \mathrm{b}}\end{array}$ & $\begin{array}{c}\text { Homogenate + spiking } \\
\text { AA }\left(\mu g \mathrm{~mL}^{-1}\right)^{\mathrm{a}, \mathrm{b}}\end{array}$ & $\begin{array}{c}\text { Recovery } \\
(\%) \\
\end{array}$ \\
\hline \multirow{2}{*}{ Celaskon (tablets) } & \multirow{2}{*}{$0.2(2.0)$} & $5.0 \pm 0.2(4.0)$ & $15.6 \pm 0.9(5.8)$ & 105 \\
\hline & & $15.9 \pm 0.9(5.7)$ & $24.3 \pm 1.9(7.8)$ & 95 \\
\hline \multirow{2}{*}{ Citrus aurantium } & \multirow{2}{*}{$0.1(2.3)$} & $5.1 \pm 0.1(1.9)$ & $9.7 \pm 0.3(3.1)$ & 103 \\
\hline & & $15.3 \pm 1.0(6.5)$ & $20.3 \pm 1.6(7.9)$ & 104 \\
\hline \multirow{2}{*}{ Human serum } & \multirow{2}{*}{$7.1 \pm \quad 0.3(4.2)$} & $4.8 \pm 0.2(4.2)$ & $12.1 \pm 0.6(5.0)$ & 102 \\
\hline & & $15.1 \pm 0.9(6.0)$ & $21.7 \pm 1.8(8.3)$ & 98 \\
\hline
\end{tabular}

\section{Conclusions}

High performance liquid chromatography coupled with an eight channel electrochemical detector appears to be a very suitable analytical instrument for sensitive ascorbic acid determination. Using the optimized technique ascorbic acid was determined in pharmaceutical preparations, fruits and human blood serum samples.

\section{Acknowledgements}

Financial support from MSMT 6215712402 and NAZVA QH8223 is greatly acknowledged.

\section{References}

1. Velisek, J.; Cejpek, K. Biosynthesis of food constituents: Vitamins. 2. Water-soluble vitamins: part 1 - a review. Czech. J. Food Sci. 2007, 25, 49-64.

2. Linster, C.L.; Van Schaftingen, E. Vitamin C - Biosynthesis, recycling and degradation in mammals. Febs J. 2007, 274, 1-22.

3. Davey, M.W.; Van Montagu, M.; Inze, D.; Sanmartin, M.; Kanellis, A.; Smirnoff, N.; Benzie, I.J.J.; Strain, J.J.; Favell, D.; Fletcher, J. Plant L-ascorbic acid: chemistry, function, metabolism, bioavailability and effects of processing. J. Sci. Food Agric. 2000, 80, 825-860.

4. Noctor, G.; Foyer, C.H. Ascorbate and glutathione: Keeping active oxygen under control. Annu. Rev. Plant Physiol. Plant Molec. Biol. 1998, 49, 249-279.

5. Kleszczewska, E. L-Ascorbic acid - clinical use, toxicity, properties, methods of determination and application in chemical analysis. Pharmazie 2000, 55, 640-644. 
6. Meister, A. Glutathione Ascorbic-Acid Antioxidant System in Animals. J. Biol. Chem. 1994, 269, 9397-9400.

7. Englard, S.; Seifter, S. The Biochemical Functions of Ascorbic-Acid. Annu. Rev. Nutr. 1986, 6, 365-406.

8. Levine, M.; Rumsey, S.C.; Daruwala, R.; Park, J.B.; Wang, Y.H. Criteria and recommendations for vitamin C intake. JAMA-J. Am. Med. Assoc. 1999, 281, 1415-1423.

9. Gomez-Romero, M.; Arraez-Roman, D.; Segura-Carretero, A.; Fernandez-Gutierrez, A. Analytical determination of antioxidants in tomato: Typical components of the Mediterranean diet. J. Sep. Sci. 2007, 30, 452-461.

10. Deicher, R.; Horl, W.H. Vitamin C in chronic kidney disease and hemodialysis patients. Kidney Blood Pressure Res. 2003, 26, 100-106.

11. Ogiri, Y.; Sun, F.; Hayami, S.; Fujimura, A.; Yamamoto, K.; Yaita, M.; Kojo, S. Very low vitamin $\mathrm{C}$ activity of orally administered L-dehydroascorbic acid. J. Agric. Food Chem. 2002, 50, 227-229.

12. Prasad, B.B.; Tiwari, K.; Singh, M.; Sharma, P.S.; Patel, A.K.; Srivastava, S. Molecularly imprinted polymer-based solid-phase microextraction fiber coupled with molecularly imprinted polymer-based sensor for ultratrace analysis of ascorbic acid. J. Chromatogr. A 2008, 1198, 5966.

13. Karlsen, A.; Blomhoff, R.; Gundersen, T.E. Stability of whole blood and plasma ascorbic acid. Eur. J. Clin. Nutr. 2007, 61, 1233-1236.

14. Yao, X.; Wang, Y.T.; Chen, G. Simultaneous determination of am aminothiols, ascorbic acid and uric acid in biological samples by capillary electrophoresis with electrochemical detection. Biomed. Chromatogr. 2007, 21, 520-526.

15. Koide, K.; Zhang, X.M.; Ohishi, K.; Usami, Y.; Hotta, Y.; Hiramitsu, T. Ascorbic acid concentration in rabbit vitreous measured by microdialysis with HPLC-electrochemical detection before and after vitreous surgery. Exp. Eye Res. 2006, 82, 868-873.

16. Cofan, C.; Radovan, C. Simultaneous chronoamperometric sensing of ascorbic acid and acetaminophen at a boron-doped diamond electrode. Sensors 2008, 8, 3952-3969.

17. Wang, Y.; Xu, H.; Zhang, J.M.; Li, G. Electrochemical sensors for clinic analysis. Sensors 2008, 8, 2043-2081.

18. Yogeswaran, U.; Chen, S.M. A review on the electrochemical sensors and biosensors composed of nanowires as sensing material. Sensors 2008, 8, 290-313.

19. Chen, J.; Fang, Y.J. Flow injection technique for biochemical analysis with chemiluminescence detection in acidic media. Sensors 2007, 7, 448-458.

20. Shaidarova, L.G.; Gedmina, A.V.; Chelnokova, I.A.; Budnikov, G.K. Electrocatalytic oxidation and flow-injection determination of ascorbic acid at a graphite electrode modified with a polyaniline film containing electrodeposited palladium. J. Anal. Chem. 2006, 61, 601-608.

21. Matos, R.C.; Augelli, M.A.; Lago, C.L.; Angnes, L. Flow injection analysis-amperometric determination of ascorbic and uric acids in urine using arrays of gold microelectrodes modified by electrodeposition of palladium. Anal. Chim. Acta 2000, 404, 151-157. 
22. Janda, P.; Weber, J.; Dunsch, L.; Lever, A.B.P. Detection of ascorbic acid using a carbon fiber microelectrode coated with cobalt tetramethylpyridoporphyrazine. Anal. Chem. 1996, 68, 960965.

23. Behrens, W.A.; Madere, R. A Highly Sensitive High-Performance Liquid-Chromatography Method for the Estimation of Ascorbic and Dehydroascorbic Acid in Tissues, Biological-Fluids, and Foods. Anal. Biochem. 1987, 165, 102-107.

24. Shakya, R.; Navarre, D.A. Rapid screening of ascorbic acid, glycoalkaloids, and phenolics in potato using high-performance liquid chromatography. J. Agric. Food Chem. 2006, 54, 52535260 .

25. Melendez-Martinez, A.J.; Vicario, I.M.; Heredia, F.J. Provitamin A carotenoids and ascorbic acid contents of the different types of orange juices marketed in Spain. Food Chem. 2007, 101, 177184.

26. Wang, J.; Chatrathi, M.P.; Tian, B.M.; Polsky, R. Microfabricated electrophoresis chips for simultaneous bioassays of glucose, uric acid, ascorbic acid, and acetaminophen. Anal. Chem. 2000, 72, 2514-2518.

27. Davey, M.W.; Bauw, G.; VanMontagu, M. Simultaneous high-performance capillary electrophoresis analysis of the reduced and oxidised forms of ascorbate and glutathione. $J$. Chromatogr. B 1997, 697, 269-276.

28. Klejdus, B.; Petrlova, J.; Potesil, D.; Adam, V.; Mikelova, R.; Vacek, J.; Kizek, R.; Kuban, V. Simultaneous determination of water- and fat-soluble vitamins in pharmaceutical preparations by high-performance liquid chromatography coupled with diode array detection. Anal. Chim. Acta 2004, 520, 57-67.

29. Wu, T.; Guan, Y.Q.; Ye, J.N. Determination of flavonoids and ascorbic acid in grapefruit peel and juice by capillary electrophoresis with electrochemical detection. Food Chem. 2007, 100, 1573 1579 .

30. Sun, X.M.; Niu, Y.; Bi, S.; Zhang, S.S. Determination of ascorbic acid in individual rat hepatocyte by capillary electrophoresis with electrochemical detection. J. Chromatogr. B 2008, 870, 46-50.

31. Zuo, F.; Luo, C.H.; Zheng, Z.H.; Ding, X.B.; Peng, Y.X. Supramolecular assembly of betacyclodextrin-capped gold nanoparticles on ferrocene-functionalized ITO surface for enhanced voltammetric analysis of ascorbic acid. Electroanalysis 2008, 20, 894-899.

32. Razmi, H.; Harasi, M. Voltammetric behavior and amperometric determination of ascorbic acid at cadmium pentacyanonitrosylferrate film modified GC electrode. Int. J. Electrochem. Sci. 2008, 3, 82-95.

33. Abbaspour, A.; Khajehzadeh, A.; Noori, A. A simple and selective sensor for the determination of ascorbic acid in vitamin C tablets based on paptode. Anal. Sci. 2008, 24, 721-725.

34. Liu, H.Q.; Tian, Y. Analytical application of pyramidal, rodlike, and spherical gold nanostructures: Simultaneous detection of ascorbic acid and uric acid. Electroanalysis 2008, 20, 1227-1233.

35. Dai, H.; Wu, X.P.; Wang, Y.M.; Zhou, W.C.; Chen, G.N. An electrochemiluminescent biosensor for vitamin $\mathrm{C}$ based on inhibition of luminol electrochemiluminescence on graphite/poly(methyl methacrylate) composite electrode. Electrochim. Acta 2008, 53, 5113-5117. 
36. Nezamzadeh, A.; Amini, M.K.; Faghihian, H. Square-wave voltammetric determination of ascorbic acid based on its electrocatalytic oxidation at zeolite-modified carbon-paste electrodes. Int. J. Electrochem. Sci. 2007, 2, 583-594.

37. Kizek, R.; Vacek, J.; Trnkova, L.; Jelen, F. Cyclic voltammetric study of the redox system of glutathione using the disulfide bond reductant tris(2-carboxyethyl)phosphine. Bioelectrochemistry 2004, 63, 19-24.

38. Mikelova, R.; Baloun, J.; Petrlova, J.; Adam, V.; Havel, L.; Petrek, J.; Horna, A.; Kizek, R. Electrochemical determination of Ag-ions in environment waters and their action on plant embryos. Bioelectrochemistry 2007, 70, 508-518.

39. Causon, R. Validation of chromatographic methods in biomedical analysis - Viewpoint and discussion. J. Chromatogr. B 1997, 689, 175-180.

40. Bugianesi, R.; Serafini, M.; Simone, F.; Wu, D.Y.; Meydani, S.; Ferro-Luzzi, A.; Azzini, E.; Maiani, G. High-performance liquid chromatography with coulometric electrode array detector for the determination of quercetin levels in cells of the immune system. Anal. Biochem. 2000, 284, 296-300.

41. Petrlova, J.; Mikelova, R.; Stejskal, K.; Kleckerova, A.; Zitka, O.; Petrek, J.; Havel, L.; Zehnalek, J.; Adam, V.; Trnkova, L.; Kizek, R. Simultaneous determination of eight biologically active thiol compounds using gradient elution-liquid chromatography with Coul-Array detection. J. Sep. Sci. 2006, 29, 1166-1173.

42. Long, G.L.; Winefordner, J.D. Limit of Detection. Anal. Chem. 1983, 55, A712-A724.

43. Masarik, M.; Stobiecka, A.; Kizek, R.; Jelen, F.; Pechan, Z.; Hoyer, W.; Jovin, T.M.; Subramaniam, V.; Palecek, E. Sensitive electrochemical detection of native and aggregated alphasynuclein protein involved in Parkinson's disease. Electroanalysis 2004, 16, 1172-1181.

44. Kizek, R.; Trnkova, L.; Palecek, E. Determination of metallothionein at the femtomole level by constant current stripping chronopotentiometry. Anal. Chem. 2001, 73, 4801-4807.

45. Hubalek, J.; Hradecky, J.; Adam, V.; Krystofova, O.; Huska, D.; Masarik, M.; Trnkova, L.; Horna, A.; Klosova, K.; Adamek, M.; Zehnalek, J.; Kizek, R. Spectrometric and voltammetric analysis of urease - Nickel nanoelectrode as an electrochemical sensor. Sensors 2007, 7, 12381255.

46. Petrlova, J.; Krizkova, S.; Supalkova, V.; Masarik, M.; Adam, V.; Havel, L.; Kramer, K.J.; Kizek, $\mathrm{R}$. The determination of avidin in genetically modified maize by voltammetric techniques. Plant Soil Environ. 2007, 53, 345-349.

47. Petrlova, J.; Krizkova, S.; Zitka, O.; Hubalek, J.; Prusa, R.; Adam, V.; Wang, J.; Beklova, M.; Sures, B.; Kizek, R. Utilizing a chronopotentiometric sensor technique for metallothionein determination in fish tissues and their host parasites. Sens. Actuator B-Chem. 2007, 127, 112-119.

48. Petrlova, J.; Masarik, M.; Potesil, D.; Adam, V.; Trnkova, L.; Kizek, R. Zeptomole detection of streptavidin using carbon paste electrode and square wave voltammetry. Electroanalysis 2007, 19, 1177-1182.

49. Fabrik, I.; Krizkova, S.; Huska, D.; Adam, V.; Hubalek, J.; Trnkova, L.; Eckschlager, T.; Kukacka, J.; Prusa, R.; Kizek, R. Employment of electrochemical techniques for metallothionein determination in tumour cell lines and patients with a tumour disease. Electroanalysis 2008, 20, 1521-1532. 
50. Fabrik, I.; Ruferova, Z.; Hilscherova, K.; Adam, V.; Trnkova, L.; Kizek, R. A determination of metallothionein in larvae of freshwater midges (Chironomus riparius) using Brdicka reaction. Sensors 2008, 8, 4081-4094.

51. Adam, V.; Baloun, J.; Fabrik, I.; Trnkova, L.; Kizek, R. An electrochemical detection of metallothioneins in nanolitres at zeptomole level. Sensors 2008, 8, 2293-2305.

52. Adam, V.; Blastik, O.; Krizkova, S.; Lubal, P.; Kukacka, J.; Prusa, R.; Kizek, R. Application of the Brdicka reaction in determination of metallothionein in patients with tumours. Chem. Listy 2008, 102, 51-58.

53. Adam, V.; Zitka, O.; Dolezal, P.; Zeman, L.; Horna, A.; Hubalek, J.; Sileny, J.; Krizkova, S.; Trnkova, L.; Kizek, R. Lactoferrin isolation using monolithic column coupled with spectrometric or micro-amperometric detector. Sensors 2008, 8, 464-487.

54. Zitka, O.; Stejskal, K.; Kleckerova, A.; Adam, V.; Beklova, M.; Horna, A.; Supalkova, V.; Havel, L.; Kizek, R. Utilizing electrochemical techniques for detection of biological samples. Chem. Listy 2007, 101, 225-231.

55. Kand'ar, R.; Zakova, P.; Lotkova, H.; Kucera, O.; Cervinkova, Z. Determination of reduced and oxidized glutathione in biological samples using liquid chromatography with fluorimetric detection. J. Pharm. Biomed. Anal. 2007, 43, 1382-1387.

56. Supalkova, V.; Huska, D.; Diopan, V.; Hanustiak, P.; Zitka, O.; Stejskal, K.; Baloun, J.; Pikula, J.; Havel, L.; Zehnalek, J.; Adam, V.; Trnkova, L.; Beklova, M.; Kizek, R. Electroanalysis of plant thiols. Sensors 2007, 7, 932-959.

57. Supalkova, V.; Petrek, J.; Baloun, J.; Adam, V.; Bartusek, K.; Trnkova, L.; Beklova, M.; Diopan, V.; Havel, L.; Kizek, R. Multi-instrumental investigation of affecting of early somatic embryos of Spruce by cadmium(II) and lead(II) ions. Sensors 2007, 7, 743-759.

58. Supalkova, V.; Beklova, M.; Baloun, J.; Singer, C.; Sures, B.; Adam, V.; Huska, D.; Pikula, J.; Rauscherova, L.; Havel, L.; Zehnalek, J.; Kizek, R. Affecting of aquatic vascular plant Lemna minor by cisplatin revealed by voltammetry. Bioelectrochemistry 2008, 72, 59-65.

59. Krizkova, S.; Ryant, P.; Krystofova, O.; Adam, V.; Galiova, M.; Beklova, M.; Babula, P.; Kaiser, J.; Novotny, K.; Novotny, J.; Liska, M.; Malina, R.; Zehnalek, J.; Hubalek, J.; Havel, L.; Kizek, R. Multi-instrumental analysis of tissues of sunflower plants treated with silver(I) ions - Plants as bioindicators of environmental pollution. Sensors 2008, 8, 445-463.

60. Ryant, P.; Dolezelova, E.; Fabrik, I.; Baloun, J.; Adam, V.; Babula, P.; Kizek, R. Electrochemical determination of low molecular mass thiols content in potatoes (Solanum tuberosum) cultivated in the presence of various sulphur forms and infected by late blight (Phytophora infestans). Sensors 2008, 8, 3165-3182.

61. Babula, P.; Huska, D.; Hanustiak, P.; Baloun, J.; Krizkova, S.; Adam, V.; Hubalek, J.; Havel, L.; Zemlicka, M.; Horna, A.; Beklova, M.; Kizek, R. Flow injection analysis coupled with carbon electrodes as the tool for analysis of naphthoquinones with respect to their content and functions in biological samples. Sensors 2006, 6, 1466-1482.

62. Supalkova, V.; Stavelikova, H.; Krizkova, S.; Adam, V.; Horna, A.; Havel, L.; Ryant, P.; Babula, P.; Kizek, R. Study of capsaicin content in various parts of pepper fruit by liquid chromatography with electrochemical detection. Acta Chim. Slov. 2007, 54, 55-59. 
63. Kolouchova-Hanzlikova, I.; Melzoch, K.; Filip, V.; Smidrkal, J. Rapid method for resveratrol determination by HPLC with electrochemical and UV detections in wines. Food Chem. 2004, 87, 151-158.

64. Diopan, V.; Babula, P.; Shestivska, V.; Adam, V.; Zemlicka, M.; Dvorska, M.; Hubalek, J.; Trnkova, L.; Havel, L.; Kizek, R. Electrochemical and spectrometric study of antioxidant activity of pomiferin, isopomiferin, osajin and catalposide. J. Pharm. Biomed. Anal. 2008, 48, 127-133.

65. Supalkova, V.; Petrek, J.; Havel, L.; Krizkova, S.; Petrlova, J.; Adam, V.; Potesil, D.; Babula, P.; Beklova, M.; Horna, A.; Kizek, R. Electrochemical sensors for detection of acetylsalicylic acid. Sensors 2006, 6, 1483-1497.

66. Mikelova, R.; Hodek, P.; Hanustiak, P.; Adam, V.; Krizkova, S.; Havel, L.; Stiborova, M.; Horna, A.; Beklova, M.; Trnkova, L.; Kizek, R. Determination of isoflavones using liquid chromatography with electrochemical detection. Acta Chim. Slov. 2007, 54, 92-97.

67. Billova, S.; Kizek, R.; Jelen, F.; Novotna, P. Square-wave voltammetric determination of cefoperazone in a bacterial culture, pharmaceutical drug, milk, and urine. Anal. Bioanal. Chem. 2003, 377, 362-369.

68. Diculescu, V.C.; Vivan, M.; Brett, A.M.O. Voltammetric behavior of antileukemia drug glivec. Part III: In situ DNA oxidative damage by the Glivec electrochemical metabolite. Electroanalysis 2006, 18, 1963-1970.

69. Beklova, M.; Krizkova, S.; Supalkova, V.; Mikelova, R.; Adam, V.; Pikula, J.; Kizek, R. Determination of bromadiolone in pheasants and foxes by differential pulse voltammetry. Int. J. Environ. Anal. Chem. 2007, 87, 459-469.

70. Krizkova, S.; Beklova, M.; Pikula, J.; Adam, V.; Horna, A.; Kizek, R. Hazards of secondary bromadiolone intoxications evaluated using high-performance liquid chromatography with electrochemical detection. Sensors 2007, 7, 1271-1286.

71. Potesil, D.; Petrlova, J.; Adam, V.; Vacek, J.; Klejdus, B.; Zehnalek, J.; Trnkova, L.; Havel, L.; Kizek, R. Simultaneous femtomole determination of cysteine, reduced and oxidized glutathione, and phytochelatin in maize (Zea mays L.) kernels using high-performance liquid chromatography with electrochemical detection. J. Chromatogr. A 2005, 1084, 134-144.

72. Wang, J. Analytical Electrochemistry, Wiley-VCH: New York, 2000.

(C) 2008 by the authors; licensee Molecular Diversity Preservation International, Basel, Switzerland. This article is an open-access article distributed under the terms and conditions of the Creative Commons Attribution license (http://creativecommons.org/licenses/by/3.0/). 